\title{
MEDŽIMURJE HORSE POPULATION IN SLOVENIA
}

\author{
Klemen POTOČNIK ${ }^{1}$, Mojca SIMČIČ ${ }^{2}$, Angela CIVIDINI ${ }^{3}$, Andrej ŠALEHAR ${ }^{4}$, Matjaž \\ MESARIČ $^{5}$, Janez RUS ${ }^{5}$, Tatjana KAVAR ${ }^{6}$, Peter DOVČ $^{7}$
}

Received September 05, 2011; accepted September 22, 2011. Delo je prispelo 05. septembra 2011, sprejeto 22. septembra 2011.

\begin{abstract}
Medžimurje horse population in Slovenia
In the nineteenth and early twentieth century the Medžimurje horse played an important role as a draft and working horse in the river Mura region. Nowadays, this area is split between Hungary, Austria, Slovenia and Croatia. In the frame of the project "Management of traditional transboundary breeds on example of a nearly forgotten breed the Murinsulaner", we collected data for cold blooded horses similar to the Medžimurje horse. Horses of this type do not exist in Austria anymore, in Croatia they were registered as an authothonous breed »Medjimurje horse«, and in Slovenia and Hungary this horse has a special section in the stud book for cold blooded horses as a Medžimurje type of horse. The Slovenian part of the population of the Medžimurje horse is quite heterogeneous regarding body measures. With respect to the scoring system used in the above mentioned project, the majority of scored animals were classified as »desired « or »satisfactory«. In order to further develop or to preserve this type of horse or to form a consolidated breed we would have to make a breeding program which would prevent mating among related animals and to cooperate with neighbouring countries in the field of breeding and selection. The only hope to preserve this type of horse on the long term in the region is by using it as a tourist attraction for carriage riding and/or as a draft horse in agriculture in marginal regions.
\end{abstract}

Key words: horses / breeds / Medžimurje horse / history / scoring / genetic diversity / conservation

\section{Populacija medžimurskega konja $v$ Sloveniji}

Medžimurski konj je imel pomembno vlogo pri transportu in delu $\mathrm{v}$ devetnajstem in $\mathrm{v}$ začetku dvajsetega stoletja na področju ob Muri. Danes je to področje razdeljeno med Madžarsko, Avstrijo, Slovenijo in Hrvaško. V okviru projekta "Upravljanje tradicionalnih čezmejnih pasem na primeru skoraj pozabljene pasme, medžimurski konj", smo zbrali podatke o hladnokrvnih konjih, ki so v tipu medžimurskega konja. V Avstriji takih konj ni več, na Hrvaškem so konje tega tipa registrirali kot avtohtono pasmo medjimurski konj, na Madžarskem in v Sloveniji pa se ti konji vodijo kot poseben oddelek (medžimurski tip) rodovniške knjige za hladnokrvne konje. Slovenski del populacije v tipu medžimurskega konja je glede na telesne mere precej neizenačen. Upoštevaje sistem ocenjevanja, ki je bil razvit v okviru omenjenega projekta, večina ocenjenih živali sodi v t.i. razred zaželeno oz. zadovoljivo. Za razvoj in ohranitev tega tipa konja oz. formiranje pasme, bo potrebno izdelati rejski program, ki bo zagotavljal preprečevanje parjenja $\mathrm{v}$ sorodstvu in razviti sodelovanje s sosednjimi državami na področju reje in selekcije tega tipa konj. Ne nazadnje je dolgoročen obstoj tega tipa konja mogoče zagotoviti le z njegovo uporabo za delo $\mathrm{v}$ kmetijstvu in $\mathrm{v}$ turizmu.

Ključne besede: konji / pasme / medžimurski konj / zgodovina / ocenjevanje / genetska pestrost / ohranjanje

\footnotetext{
1 Univ. of Ljubljana, Biotechnical Fac., Dept. of Animal Science, Groblje 3, Domžale, SI-1230, Slovenia, Lecturer, Ph.D., M.Sc., e-mail: Klemen.Potocnik@bf.uni-lj.si

2 Same address as 1

3 Same address as 1, M.Sc

4 Same address as 1, Professor Emeritus, Prof., Ph.D.

5 Univ. of Ljubljana, Veterinary Fac., Cesta v Mestni Log 47, Ljubljana, SI-1000, Slovenia

6 Same address as 1, Ph.D.

7 Same address as 1, Prof., Ph.D
} 


\section{INTRODUCTION}

Medžimurje horses also known as 'Murinsulaner', 'Muraközi' and 'Muraköser Pferd' were bred in the past on the territory of the river Mura, which nowadays belong to four countries: Austria, Croatia, Hungary and Slovenia. Today, the population of Medžimurje horse in Croatia, Hungary and Slovenia is nearly extinct, while in Austria this horse breed already disappeared. We consider Medžimurje horse as a special type of Slovenian coldblooded horse. Documents from the beginning of the $20^{\text {th }}$ century show that Medžimurje horse was very important in the past in the Mura region, especially for work in agriculture. In other regions it was well known as an easy to handle horse with modest needs. In the year 2008 an international cooperation of four countries within the project accepted by the ERFP (European Regional Focal Point for Animal Genetic Resources), "Management of traditional transboundary breeds on example of a nearly forgotten breed the Murinsulaner", has started with the goal to preserve this horse type as a breed (Bodo et al, 2010). The population of Medžimurje horse in Slovenia has been scored with the new scoring system, established during the project. Blood samples of the most desired mares on the base of scoring system for Medžimurje horse, were collected and mtDNA analysis was performed. The aim of the study was to get an insight in the population of Medžimurje horse in Slovenia from the phenotypic and genetic point of view.

\section{MATERIAL AND METHODS}

\subsection{THE WRITTEN FACTS FROM THE HISTORI- CAL LITERATURE}

Publications from the end of the $19^{\text {th }}$ century as well as from the beginning of the $20^{\text {th }}$ century were checked carefully, especially journals, publishing articles covering agricultural topics. Old reports and documents regarding horse breeding were also taken into account. In addition, all available agricultural books containing horse breeding chapters published in the past were also reviewed.

\subsection{EXTERIOR TRAITS SCORING}

New scoring system for Medžimurje type of horses was prepared in order to evaluate traits that potentially provide a competitive advantage of Medžimurje horse over the other cold-blooded horse breeds. A simple scoring system included measured as well as scored traits. Measured traits were: wither height, chest girth and can- non bone circumference. Coat colour was described as chestnut, brown, black or other. The score traits included were: body size, head, mane, fetlock hair, bony frame, and crouThe temperament, working ability, walk and trot were determined by the questionnaire. Each trait had only three possible scores: desired (1), satisfactory (2) and disliked (3).

\subsection{MOLECULAR GENETIC ANALYSIS OF mtDNA}

The upstream part of the control region from nt 15542 to nt 15834 (GenBank X79547; Xu and Arnason, 1994) was sequenced for 15 most desirable mares regarding the scoring system for Medžimurje horse. mtDNA was extracted from blood samples following a standard procedure (White, 1992). PCR amplification was performed on a Applied Biosystems Thermal cycler 2720 , with an annealing temperature of $54^{\circ} \mathrm{C}$ for $30 \mathrm{~s}$. Reactions $(20 \mu \mathrm{l})$ contained template DNA (50 ng), $1 \mathrm{x}$ standard Reaction Buffer $\mathrm{MgCl}_{2}$ free (Biotools, Spain), $2.5 \mathrm{mM} \mathrm{MgCl}, 25 \mu \mathrm{M}$ dNTPs, $0.5 \mathrm{U}$ DNA polymerase (Biotools, Spain) and $10 \mathrm{pmol}$ of each primer (28j: 5'-AGCCCCACTATCAACACCCAAAGC-3' and HF: 5'-CCTGAAGTAGGAACCAGATG-3'). PCR fragments were sequenced using BigDye ${ }^{\oplus}$ Terminator v3.1 Cycle Sequencing Kit and the 3130xl Genetic Analyzer. Genetic relationships among sequences were estimated using MEGA5 programme (Tamura et al., 2011).

\section{RESULTS AND DISCUSSION}

\subsection{REVIEW OF WRITTEN FACTS ABOUT MEDŽIMURJE HORSE IN THE PAST}

The newspaper articles and documents about horse breeds on Slovenian territory, revealed notes, where Medžimurje horse was mentioned. The Medžimurje horse was bred in the region of the river Mura in the Austro - Hungarian Monarchy, which now belongs to four countries Austria, Croatia, Hungary and Slovenia (Bodo et al., 2010).

Šlajpah (1926a) reported that until the year 1926 on Slovenian territory existed mainly cold-blooded horse breeds. However, the increased interest for the lighter type of horses arose gradually, especially in Medžimurje. This is also the first record that suggested conservation of specific horse breed, which was unique to the Medžimurje area. A few years later Kuhar (1933) for the first time mentioned the breed name Medžimurec (Medžimurje horse) in the article "Heavy or lighter horses". Also in »Horse breeding in Prekmurje« the horse 
from this region was described as well known and appreciated in the wider region under the name Medžimurec (Konjereja, 1933).

Kuhar (1933) further reported that the Medžimurje horses were improved with Belgian stallions. In the later annual reports the breed was named Medžimurje horse or Belgian horse in a way that the word Medžimurje horse was always followed by the word Belgian in the brackets. The word Belgian in the brackets therefore meant Medžimurje horse of the heavier type, which was the result of crossing Medžimurje mares with Belgian stallions. In the mentioned report the registrations of mares of the Medžimurje (Belgian) breed in different districts were reported. In the districts of Sveti Lenart, Ptuj and Ormož, 37 mares with foals of Medžimurje (Belgian) breed were registered in the studbook in 1934. In the districts of Dolnja Lendava and Murska Sobota 28 Medžimurje (Belgian) mares with foals were registered in the stud book in the same year (Veble, 1934a). The breeders meeting took place in March 1934 in Maribor, where the horse breeding revival in the Dravska province was discussed (Veble, 1934a). Invited experts from the Savska province confirmed the existence of a famous Medžimurje horse, which was still present, but in a slightly modified form. As a final conclusion of the meeting the guidelines for the future development of horse breeding were given. It has been suggested that Medžimurje horse should be bred in the districts of Dolnja Lendava and Murska Sobota (Veble, 1934a).

Based on the Livestock law from the $21^{\text {st }}$ December 1929, the regulations of the horse breeds distribution into districts of the Dravska province were released. According to that law the territory was divided into areas dedicated to breeding of cold-blooded horses. Further the province was divided into the district of Medžimurje horse, the district of medium-heavy Noric horse and the district of light Noric horse. IN the district of Medžimurje horse Dolnja Lendava, Gornja Radgona, municipality Štrigova, Ljutomer, Sveti Lenart in Slovenske Gorice, Maribor - left bank of the river Drava, Murska Sobota and Ptuj were included (Veble, 1934b).

Podgrajski (1935) described Medžimurje horse in the newspaper "Slovenski gospodarski list". He wrote that Medžimurje horse had always been bred in the eastern part of Slovenia. Medžimurje horse was the mediumheavy type of horse. He described it as a local fast growing horse. It was sturdy and early able to work as well as modest in the diet. Medžimurje horse was bred in Medžimurje, where also most of the trading occurred (Podgrajski, 1935).

In the book »Uzgoj konja u Medjimurju «, written by Steinhausz (1934), it was stated that Medžimurje horse

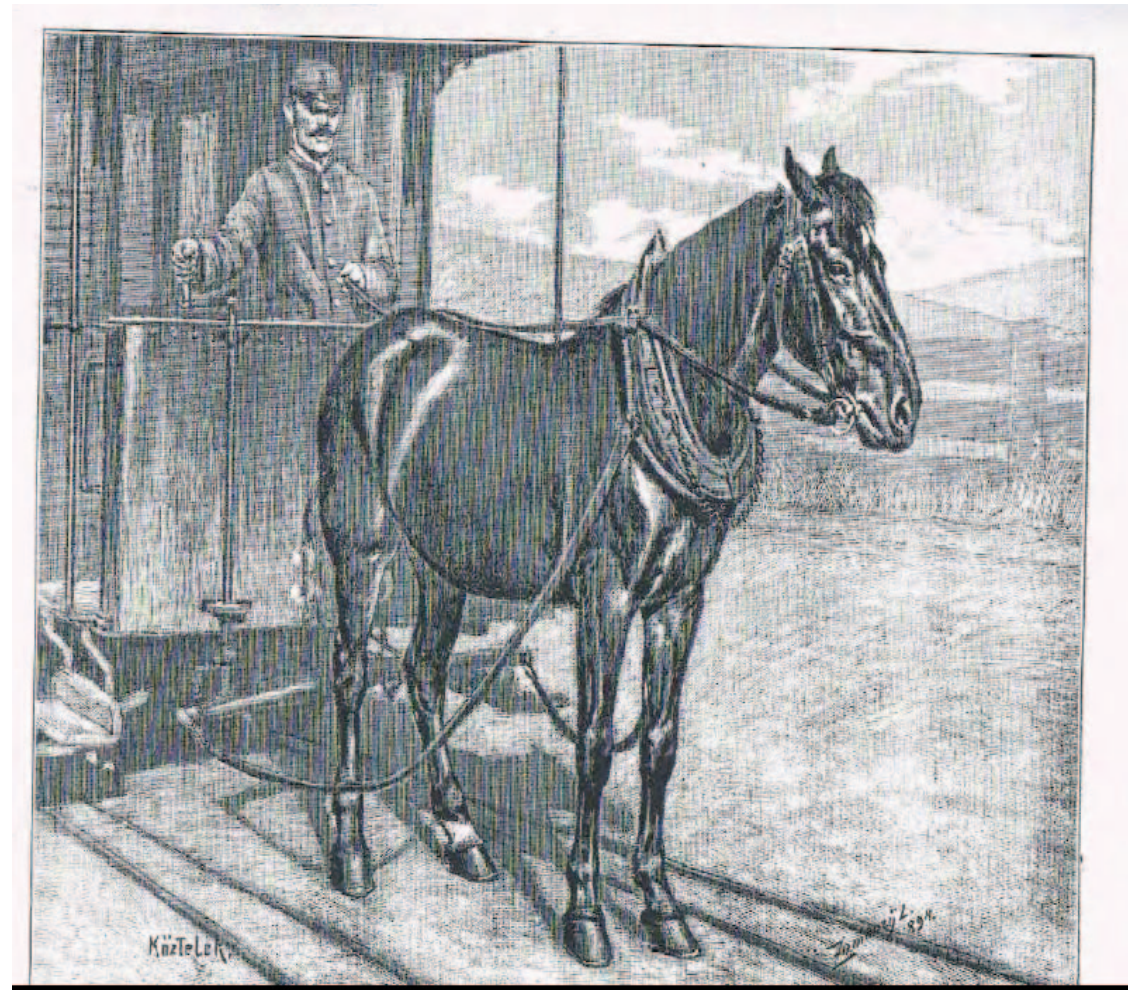

Figure 1: Medžimurje horse drawn by Lajos Zombory (Monostori, 1894)

Slika 1: Lajos Zombory: Medžimurski konj (Monostori, 1894) 
originates from improving the local mares with imported stallions. However, there were two different types of the Medžimurje horse. A lighter type originated from Hungarian, Anglo-Arab and Arab mares crossed by Noric stallions. The horses had relatively small head with large eyes, short and well placed neck, split croup, wide and deep chest and strong legs. They were $160 \mathrm{~cm}$ tall in wither. This lighter type of horse was used for long distance transports in large cities, like Vienna and Budapest as well as for harness in a tram (Fig. 1).

The heavier type of Medžimurje horse was created first by improving Arab and Anglo-Arab Hungarian mares with Noric stallions and later with Belgian stallions. Even heavier type of the Medžimurje horse resulted from crossings between the lighter type mares of the Medžimurje horse with heavy Belgian stallions in the third and fourth generation. That type of horse was larger and more similar to Belgian horses, which were well known as excellent working animals. A number of those horses were sold in other parts of Austro-Hungarian Monarchy (Steinhausz,1934; Podgrajski, 1935).

Podgrajski (1935) emphasized the need to maintain both the lighter and the heavier type of Medžimurje horse, in order to cover the needs of different breeders in the Dravska province, where the Medžimurje horse was officially confirmed as the most appropriate breed. In order to advance horse breeding and selection, the herd book was established and managed by the province Stud in Selo, near Ljubljana. The selection of male foals was introduced and the best ones were bought by the province (Podgrajski, 1935).

Veble (1936a) put together the data of province best stallions in private care in the Annual report 1936. Among these stallions were also Medžimurje breed stallions. In the same report (Veble, 1936a) the information of the number of registered mares in the pedigree in the years 1934, 1935 and 1936 was published. The number of registered mares of Medžimurje breed increased in the districts of Sveti Lenart, Ptuj and Ormož between the years 1934 and 1936. In the year 1936, 47 mares were registered in the herd book of the Medžimurje horse. All Medžimurje horses registered in a herd book were also stamped on the left side of the neck under the mane with the letter $\mathbf{M}$ or $\mathbf{m}$ (Veble, 1936a).

\subsection{EXTERIOR TRAITS (CONFORMATION) SCORING}

In the north-eastern part of Slovenia (Haloze and Goričko), 25 farms with at least one mare included in the Breeding programme of Slovenian cold-blooded horse were visited. All scored mares were divided in three classes: desired (1), satisfactory (2) and disliked (3) for the breeding in the type of Slovenian Medžimurje horse. In addition, five stallions in the Medžimurje type from the Slovenian cold-blooded stallion population were scored and measured using the same scoring system. In the year 2010 those chosen stallions were distributed to the breeding stations where mares of Medžimurje horse were located.

Table 2: Distribution of coat colours among mares of the Medžimurje breed in Slovenia

Preglednica 2: Razporeditev barve dlake pri kobilah medžimurske pasme $v$ Sloveniji

\begin{tabular}{ll}
\hline Coat colour & The share of mares (\%) \\
\hline Chestnut & 10 \\
Brown & 47 \\
Black & 40 \\
Other & 3 \\
\hline
\end{tabular}

All together 41 mares were measured and scored as desired and satisfactory (Table 1). Mares of the Slovenian population of Medžimurje horse had the average height in wither $149 \mathrm{~cm}$ and chest girth $187 \mathrm{~cm}$. The average cannon bone circumference was $21.4 \mathrm{~cm}$. However, the population was very diverse what clearly show the minimum and maximum values.

Great variability existed also in the coat colour ( $\mathrm{Ta}$ ble 2). Almost one half (47\%) of the scored mares were brown coat colour, followed by black (40\%) and chestnut (10\%) animals.

However, 41 mares had average score desired (1) or satisfactory (2) for all traits (Fig. 2). More than 50\% of mares had score desired (1) for body size, mane, bony frame, croup and working ability. There were also more than $45 \%$ of mares with the score desired (1) for head and temperament. On the other hand, the majority of

Table 1: Mares of Medžimurje breed in Slovenia scored as desired and satisfactory in average

Preglednica 1: Kobile medžimurske pasme $v$ Sloveniji so bile v povprečju ocenjene zoceno zaželeno in zadovoljivo

\begin{tabular}{lllll}
\hline Trait & $\mathrm{n}$ & Mean \pm SD & Minimum & Maximum \\
\hline Wither height - stick $(\mathrm{cm})$ & 41 & $150 \pm 3.95$ & 141 & 164 \\
Chest girth $(\mathrm{cm})$ & 41 & $192 \pm 7.80$ & 179 & 211 \\
Cannon bone circumference $(\mathrm{cm})$ & 41 & $21.6 \pm 1.08$ & 20 & 25 \\
\hline
\end{tabular}




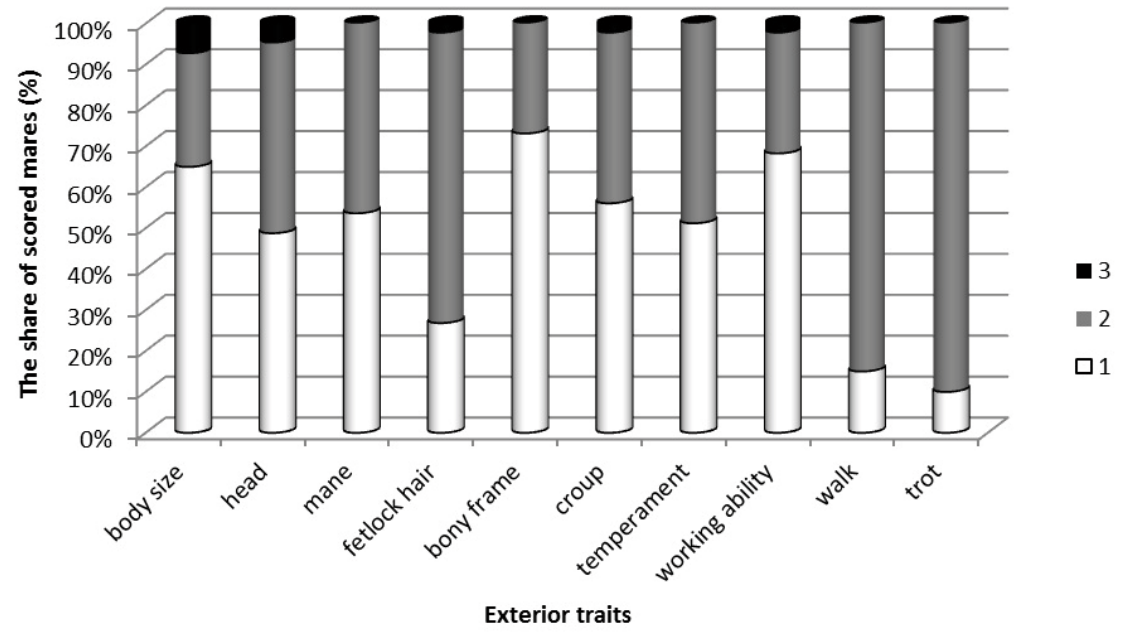

Figure 2: Score distribution by traits for 41 scored mares

Slika 2: Porazdelitev ocen za lastnosti pri 41 ocenjenih kobilah

mares (more than 70\%) had only score satisfactory (2) for fetlock hair, walk and trot. Less than $10 \%$ of mares had scored disliked (3) for all included traits. The highest share of mares (10\%) had score dislike (3) for the body frame.

\subsection{MITOCHONDRIAL DNA (MTDNA) ANALYSIS}

Sequence analysis of 15 Medžimurje horses revealed 11 distinct mtDNA haplotypes, Identical haplotype was detected for samples 2, 5 and 6 (Mur-2,5,6), samples 3 and 4 (Mur-3,4), and samples 11 and 13 (Mur-11,13).
Haplotypes of Medžimurje horse were identical or highly similar to other domestic horse haplotypes; e.g. Mur- 8 haplotype was identical to the Lipizzan haplotype A, Arabic haplotype 21, Posavina haplotype 18/156, Chinese Mongolian haplotype LIMGB 0001, Irish draft haplotype 54, Iberian ancient haplotype ATA02 etc. (in total, 33 identical hits were found by blast search in the NCBI nr database for this haplotype) (Table 3).

Eleven haplotypes of Medžimurje horse clustered into four different haplogroups: C1, C2, C3 and C4 (Fig. 3). The high matrilineal intra-breed diversity, which is typical for the majority of horse breeds, has thus also been detected in the Medžimurje horse. Only rare ex-

Table 3: Polymorhic sites among 11 haplotypes of the Medžimurje horse (Mur). For comparison, a reference haplotype of domestic horse is added

Preglednica 3: Polimorfna mesta enajstih haplotipov medžimurskega konja (Mur). Za primerjavo je dodan referenčni haplotip konja

\begin{tabular}{|c|c|c|c|c|c|c|c|c|c|c|c|c|c|c|c|c|c|c|c|c|c|c|c|}
\hline & Haplotype & $\begin{array}{l}0 \\
0 \\
0 \\
n\end{array}$ & 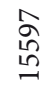 & 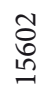 & 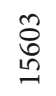 & $\begin{array}{l}\text { H' } \\
0 \\
\text { م }\end{array}$ & $\begin{array}{l}\Lambda \\
\vec{b} \\
.\end{array}$ & 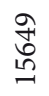 & 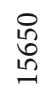 & $\begin{array}{l}\text { 命 } \\
\text { م. }\end{array}$ & $\begin{array}{l}0 \\
: 0 \\
:\end{array}$ & 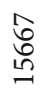 & $\begin{array}{l}\stackrel{0}{\Omega} \\
\stackrel{n}{n}\end{array}$ & 帘 & 옹 & 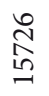 & $\begin{array}{l}\text { 亲 } \\
\text { in }\end{array}$ & 点 & $\underset{\hat{N}}{\hat{N}}$ & $\begin{array}{l}0 \\
0 \\
\stackrel{0}{n}\end{array}$ & $\begin{array}{l}\text { } \\
\stackrel{D}{1} \\
\stackrel{1}{n}\end{array}$ & $\begin{array}{l}\vec{D} \\
\stackrel{0}{\Omega}\end{array}$ & 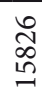 \\
\hline \multirow[t]{2}{*}{$\mathrm{C} 3 \mathrm{a}$} & Mur-1 & & & $\mathrm{T}$ & & & $\mathrm{C}$ & & & $\mathrm{C}$ & & & & & A & & & $\mathrm{T}$ & & $\mathrm{T}$ & & & \\
\hline & Mur-14 & & & $\mathrm{T}$ & & & $\mathrm{C}$ & & & $\mathrm{C}$ & & & & & A & & & & & $\mathrm{T}$ & & & \\
\hline \multirow[t]{3}{*}{$\mathrm{C} 4$} & Mur-3,4 & & & $\mathrm{T}$ & $\mathrm{C}$ & & & G & & & & & & & A & & & $\mathrm{T}$ & & & & & \\
\hline & Mur-2,5,6 & A & & & $\mathrm{C}$ & & & G & & & & & & & A & & & $\mathrm{T}$ & & & & & \\
\hline & Mur-11,13 & $\mathrm{A}$ & & $\mathrm{T}$ & $\mathrm{C}$ & A & & G & & & & & & & $\mathrm{A}$ & & & $\mathrm{T}$ & & & & & \\
\hline \multirow[t]{2}{*}{$\mathrm{C} 2$} & Mur-7 & & G & $\mathrm{T}$ & & A & & & & & & G & $\mathrm{C}$ & & A & & & $\mathrm{T}$ & G & & G & & \\
\hline & Mur-9 & & & $\mathrm{T}$ & & & & & & & & & $\mathrm{C}$ & & A & A & G & $\mathrm{T}$ & G & & & $\mathrm{T}$ & \\
\hline \multirow[t]{4}{*}{$\mathrm{C} 1$} & Mur-10 & & & & & & & & G & & A & & & & A & & & & & & & & G \\
\hline & Mur-12 & & & $\mathrm{T}$ & & & & & G & & & & & $\mathrm{T}$ & A & & & $\mathrm{T}$ & & & & & G \\
\hline & Mur-15 & & & $\mathrm{T}$ & & & & & & & & & & & & & & & & & & & G \\
\hline & Mur-8 & & & & & & & & & & & & & & & & & & & - & & & G \\
\hline
\end{tabular}




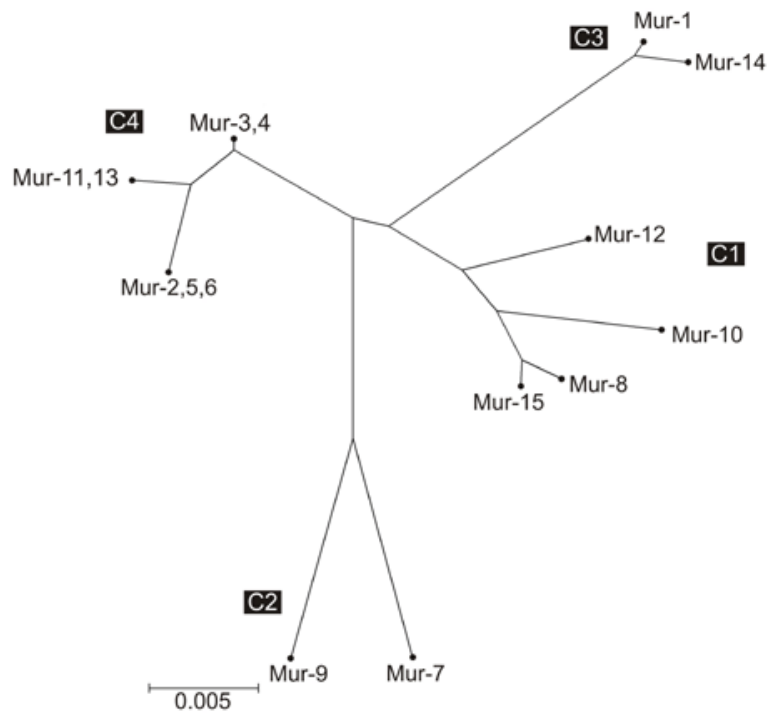

Figure 3: Genetic relationship among 11 haplotypes of Medžimurje horse

Slika 3: Genetski odnosi med 11 haplotipi pri medžimurskem konju

ceptions with low intra breed diversity are represented by closed breeds with a reduced effective population size (e.g. the Sorraia horse - in which only two distinct haplotypes were found (Luis et al., 2002)). The high presentday diversity is a consequence of the high overall diversity in the wild horse populations from Eurasia, from which numerous matrilines were incorporated into the gene pool of domestic horses (Vila et al., 2001; Kavar and Dovč, 2008). Due to the high migration rate before and after the horse domestication, the phylogeographic structure is very weak, thus the majority of present-day horse breeds includes haplotypes from all four haplogroups (C1, C2, C3 and C4). Up to now, only few associations between haplotype and geographical origin have been reported; i.e. between haplogroup C3a and European ponies (Jansen et al., 2002), and between C2 haplogroup and Eastern horse populations (McGahern et al., 2006).

About 17 haplotypes are very frequent in domestic horses (Jansen et al. 2002). We assume that first domesticated mares have already had such haplotypes. These haplotypes have been detected in the ancient horse samples frequently and they are still very common in almost all horse breeds, due to the use of the same founder mares in different breeds (Luís et al., 2006). Four such haplotypes were detected in the Medžimurje horse (Mur8, Mur-2,5,6, Mur-3,4 and Mur-11,13). Over 60 identical hits can be found by blast search in NCBI nr database for one of these common haplotypes. On the other hand, for haplotypes Mur-9, Mur-14, and Mur-15 no identical hits were found in the NCBI nr database. They are probably less frequent haplotypes and not typical for any breed. Nucleotide sequences of these three haplotypes were deposited in the GenBank under Acc. Nos. JQ219938-40.

\section{CONCLUSIONS}

Conservation of ancient breeds has a great national, international and cultural relevance. The Medžimurje horse used to be and should also be in the future used for light work in the forests and in the agriculture. In addition, the Medžimurje horse as a light draft horse has at present a great chance as a touristic attraction. In Slovenia, there are still a small number of cold blooded horses of the Medžimurje type. For all measured traits, we have observed considerable variability within the breed. However, according to the scoring system, established for the purpose of our project, the majority of Medžimurje horses bred in Slovenia were scored desired (1) or satisfactory (2) regarding the type characteristics. The strict selection program, prevention of mating of related individuals, cooperation with neighbouring counties breeding the same type of cold blooded horses and extensive use of this type of horses for work and tourism could be the promising strategy for successful conservation of Medžimurje horse.

\section{REFERENCES}

Bodo I., Berger B., Caput P., Ivanković A., Kovács Z., Potočnik K. 2010. Management of traditional transboundary breeds on an example of a nearly forgotten breed, the Murinsulaner. Final report ERFP project. 39 p.

Jansen T., Forster P., Levine M.A., Oelke H., Hurles M., Renfrew C., Weber J., Olek K. 2002. Mitochondrial DNA and the origins of the domestic horse. PNAS, 99, 16: 10905-10910

Kavar T., Dovč 2008. Domestication of the horse : genetic relationships between domestic and wild horses. Livestock science, 116, 1: 1-14

Konjereja v Prekmurju. 1933. Murska krajina, 2, 7: 3-12

Kuhar Š. 1933. Težki ali lahki konj. Murska krajina, 2, 42: 3-4

Luís C., Bastos-Silveira C., Cothran E.G., Oom M.M. 2002. Variation in the mitochondrial control region sequence between the two maternal lines of the Sorraia horse breed. Genetics and Molecular Biology, 25, 3: 309-311

Luís C., Bastos-Silveira C., Cothran E.G., Oom M.M. 2006. Iberian origins of New World horse breeds. Journal of Heredity, 97, 2: 107-113

McGahern A.M., Edwards C.J., Bower M.A., Heffernan A., Park S.D., Brophy P.O., Bradley D.G., Machung D.E., Hill E.W. 2006. Mitochondrial DNA Sequence diversity in extant Irish horse populations and in ancient horses. Animal Genetics, 37, 5: 498-502

Monostori K. 1894. A muraközi ló. In: Köztelek: 102-103 
Podgrajski F. 1935. Medjimurski konj. Slovenski gospodarski list, 2, 20: 240-242

Šlajpah I. 1926a. K pasemskemu vprašanju v območju konjerejskega društva za mariborsko oblast. Konjerejec, 3, 2: 3-4

Steinhausz M. 1934. Uzgoj konja u Međimurju. Zagreb, Poljoprivredna knjižnica

Tamura K., Peterson D., Peterson N., Stecher G., Nei M., Kumar S. 2011. MEGA5: Molecular evolutionary genetics analysis using maximum likelihood, evolutionary distance, and maximum parsimony methods. Molecular Biology and Evolution, 24: 1596-1599

Veble F. 1934a. Stanje naše konjereje leta 1934, v številkah, slikah in tabelah. In: Konjerejec dravske banovine. Letno poročilo za leto 1934. Ljubljana: 4-19
Veble F. 1934b. Zakonska osnova naše konjereje. In: Konjerejec dravske banovine. Letno poročilo za leto 1934, Ljubljana: 26-33

Vilà C., Leonard J.A., Gotherstrom A., Marklund S., Sandberg K., Liden K., Wayne R.K., Ellegren H. 2001. Widespread origins of domestic horse lineages. Science, 5503, 291: 474-477

White P.S., Densmore L.D. 1992. Mitochondrial DNA isolation. In: Molecular genetic analysis of populations. A practical approach. Hoelzel A.R. (ed.). Oxford, University Press: $37-43$

Xu X., Arnason U. 1994. The complete mitochondrial DNA sequence of the horse, Equus caballus: extensive heteroplasmy of the control region. Gene 148: 357-362 